\title{
Analysis of cost structure of international road transport operators in West Pomeranian voivodship in the years 2008-2014
}

\author{
Błażej SUPROŃ
}

West Pomeranian University of Technology Szczecin, Poland

\begin{abstract}
:
Aim: The analysis of the cost structure and the factors determining these costs constitutes an important subject that is applied for both strategic planning of the company's activity and the evaluation of the actions taken before. The aim of the study was to analyze the structure of the costs incurred by transport enterprises operating in the territory of West Pomeranian Voivodeship in the period from 2008 to 2014 , as well as the factors which determined cost variations.
\end{abstract}

Design / Research methods: Literature research provided an introduction to the discussion along with an analysis of the secondary sources concerned with the subject of the study. Achieving the goals required the analysis of financial reports compiled by the enterprises examined for 2008-2014. The methods of descriptive statistics were used for collecting the data. Considering the fact that the study included more than half of the target group the results obtained can be referred with considerable caution to all other economic operators of this kind in the West Pomeranian Voivodeship.

Conclusions / findings: The results found that the costs of the enterprises examined were to the largest extent influenced by macroeconomic factors, such as interest rates, fuel prices, as well as the situation on the job market. Micro-enterprises were the most vulnerable to the changes in these factors. The study showed that there is a significant correlation between the expenses borne and the economic situation on the EU market.

Originality / value of the article: While the majority of the compilations concerning transport enterprises focuses on their general situation, the results of this study provide a thorough analysis of the internal situation of the entities examined and indicate the influence of the individual factors on the market situation of these entities. It is the first compilation focusing on transport enterprises which undertakes the analysis of the costs they incur applying such a broad aspect.

Implications of the research (if applicable): The results may be used by individuals who manage transport enterprises in order to track, within the framework of an ex post analysis, the factors influencing the costs, as well as their future optimization. From the scientific perspective, the findings may be applied for further considerations concerning the road transport sector and its market situation.

Correspondence address: Błażej Suproń, West Pomeranian University of Technology Szczecin, al. Piastów 17, 70-310 Szczecin, Poland. E-mail: bsupron@zut.edu.pl.

Received: 01-09-2017, Revised: 08-12-2017, Accepted: 18-12-2017

doi: doi: http://dx.doi.org/10.29015/cerem.537 
Limitations of the research: The main limitation of the study is the incomplete picture of the situation of all transport enterprises in West Pomeranian Voivodeship. Due to the lack of comparability of the financial data, as well as the difficulties in obtaining them, the study did not include the companies which are not required to publish financial reports and those keeping tax records. Another limitation is the lack of the data on enterprises which did not submit their reports to the relevant registers despite being obligated to do so.

Key words: costs, transport enterprises, cost structure

JEL: R41

\section{Introduction}

Costs represent a significant element in the activity of a company. The analysis of their structure and value is necessary for a sound management, strategic planning as well as decision-making as to the operations of the entity. The operations of transport companies are characterized by their highly capital-intensive nature and cost variations.

The income obtained by transport operators is the surplus between costs incurred and revenues obtained by performing transport orders. Even minor changes in terms of unit costs bring about reduced income. The costs also exert influence on the company's competitiveness. Generating lower costs not only fosters more income, which can translate into investment activity, but also contributes to having the unit price of a service reduced, thereby affecting the possibility of accepting a greater number of orders.

Thus, every manager of a transport company ought to analyze thoroughly the costs incurred so as to be able to correct the directions of the company's activity accordingly.

The development of an entity which involves continuous striving for better management effectiveness requires improvement in terms of the level as well as structure of costs. They determine the profit level. In general, in companies of the SME sector there is much flexibility relating to the trend towards cost reduction, efficient use of resources and greater importance of economies of scale, whose characteristic feature is that of falling unit costs together with an increase in their size.

The cost analysis allows one to answer a number of important questions, including the identification of factors impacting the individual cost categories. The 
aim of the study was to analyze the structure of costs incurred by the enterprises investigated over the period of 2008-2014, as well as the factors which determined changes in their costs.

\section{Transport company costs and their determinants}

Costs represent a direct factor affecting the prices of transport services. Providing transport services whose price does not cover variable costs is unviable. That is why the key question to validity of transport performance is the question as to the costs generated (Ledkewicz 2014: 145).

As the research carried out by $\mathrm{K}$. Witkowski and $\mathrm{K}$. Tanon shows, the main costs incurred by the companies in the road transport sector are those relating to the consumption of materials and energy (fuel), external services (lease costs) and costs of salaries, fees and taxes (including road toll rates) (Witkowski, Tanona 2013: 412).

Moreover, G. Zimon maintains that the transport company management policy clearly shows a downward trend in terms of salaries. He further argues that there is a fall in the fuel costs produced by renewing transport fleet, which, on the other hand, results in an increased share of lease and rental costs (Zimon 2015: 350-351).

J. Waśkiewicz draws attention to the increase in the costs arising from the toll system. His study demonstrates that in $49.6 \%$ the costs per $1 \mathrm{~km}$ are influenced by the costs of fuel and consumables, in $18.2 \%$ by drivers' pay, and in $3.9 \%$ by the costs of lease and $1.9 \%$ by toll rates (Waśkiewicz, Balke 2012: 8-9).

Drawing on the research findings cited earlier, one could argue that the main component of costs and thus of the price of transport services is the fuel price. The fuel market is subject to an ongoing fluctuation of prices. The analysis of fuel prices presented in Figure 1 for the period of 2008-2014 shows that the range of these fluctuations is very substantial. At the start of 2008 the wholesale net price of 1 liter fuel was at PLN 3.09, while at the end of 2014 it was PLN 3.91 per one liter. The year 2012 saw the highest increase in the prices, with the average price per one liter standing at PLN 4.66. Moreover, the difference between the lowest and the highest fuel price in the period in question was PLN 2.22. 
Figure 1. Average net fuel prices over the period of 2008-2014

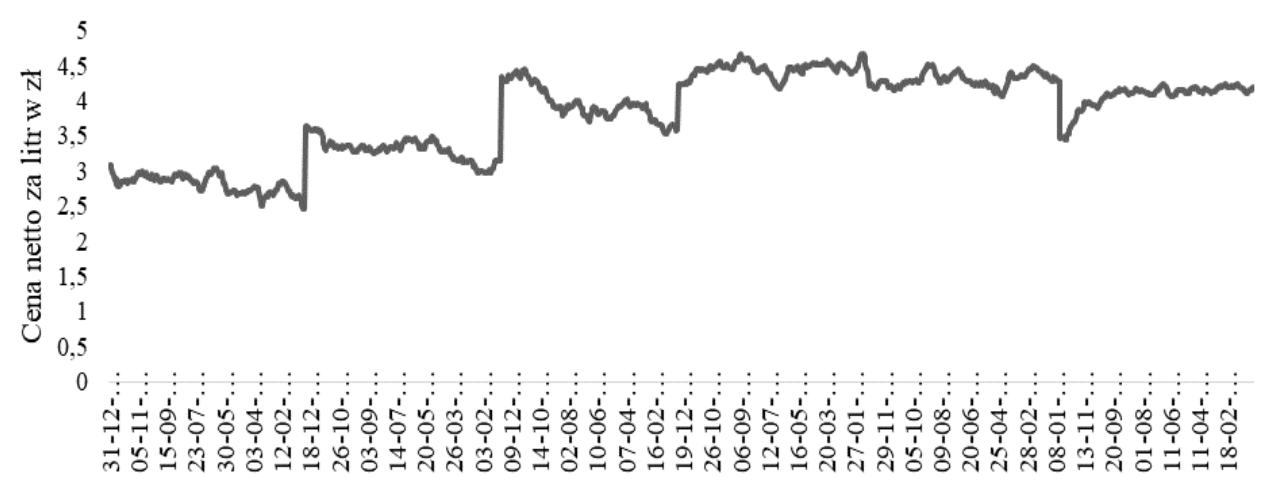

Source: self-reported data based on PKN Orlen data, http://www.orlen.pl/PL/DlaBiznesu/HurtoweCenyPaliw/Strony/Archiwum-Cen.aspx [ 15.11.2016].

Another price-determining factor in transport enterprises indicated in the previous studies is the salary of drivers, who represent the basic personal factor used in the process of the service performance. The driver's salary is comprised of several components, such as:

- overwork allowances

— allowances for working in difficult conditions,

- allowances related to the posting of workers.

The salary amount is also linked to the situation on the labor market. In Poland over the period of 2008-2014 there was a downward trend in terms of the number of professional drivers while the demand for workers grew which was the result of an increase in the number of transport companies along with that of the fleet used by transport operators.

In conducting the analysis of drivers by their competences and age one notices that the main age group in the $\mathrm{C}+\mathrm{E}$ category (truck with trailer) is made up of persons at the age of 45-54. The data show that the period of 2008-2014 saw visible aging of the staff. Furthermore, among all persons entitled to drive trucks, young people up to 24 years old represented the smallest group. During the subsequent years, although the overall number of drivers increased, the number of young people showed a downward trend, which is illustrated in Figure 2. 
Figure 2. The number of drivers with $C+E$ category by age over the period of 2008-2014

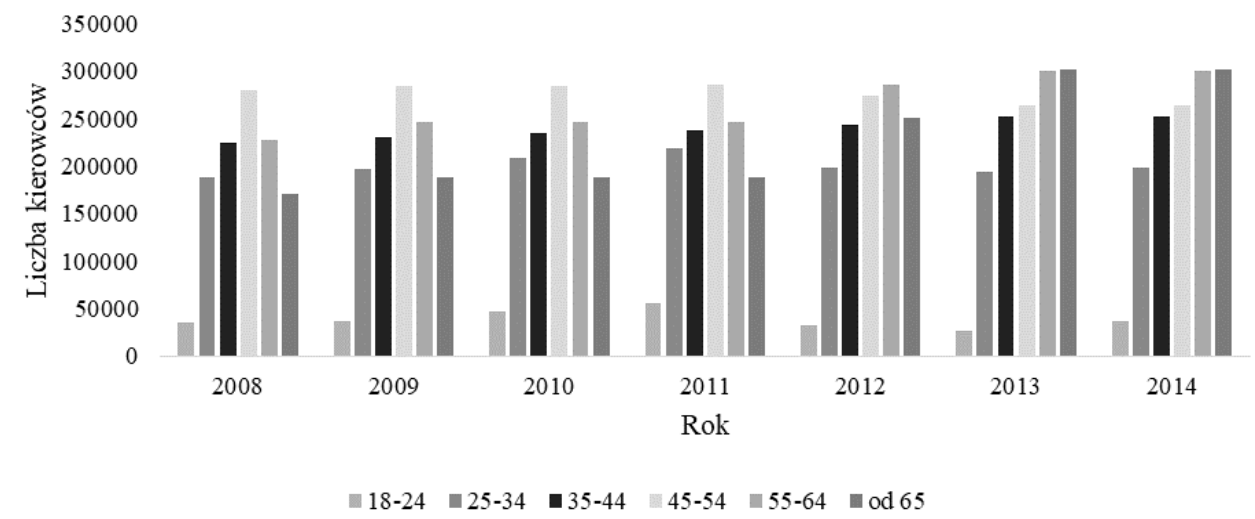

Source: self-reported data based on the CEPiK data (Central Register of Drivers and Vehicles)

The analyses of the labor market in the road transport are unambiguous in showing that this is an employee market. The key problem when estimating the exact situation of the labor market of professional drivers is the lack of studies conducted within this scope. According to the data of sector-specific services, the estimated annual demand for drivers in Poland is about 25 thousand - 35 thousand people.

That there is a shortage of drivers is further attested by the data of the Labor and Social Welfare Ministry which estimate the ratio of the labor supply shortage. This ratio is made up of the relation between the number of registered unemployed persons in the occupation indicated and the number of job offers for a particular occupation. If the ratio shows that the occupation concerned is in shortage, this signifies that the demand on the labor market is greater than the number of people looking for a job in this profession (Kocór et al. 2015: 8-9).

The value of the ratio over the period of 2008-2014 is presented in Figure 3. For drivers, this ratio showed a general link with the economic and transport situation. Moreover, its value over the entire period in question showed a shortage of drivers becoming increasingly acute especially since 2012 . 
Figure 3. The shortage ratio of category C+ E drivers over the period of 20082014

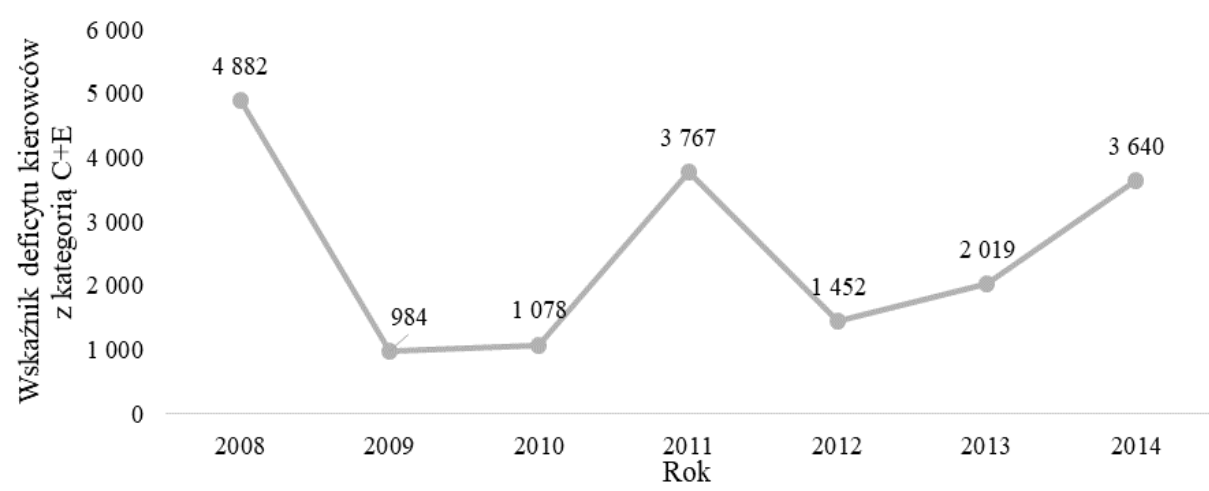

Source: self-reported data based on the shortage and surplus occupations reports over the period of 2008-2014, https://www.mpips.gov.pl/analizy-i-raporty/raporty-sprawozdania/ zawody-deficytowe-inadwyzkowe/[15.11.2016].

Among the main reasons behind the insufficient number of drivers on the market the following should be highlighted:

- high costs of obtaining licenses which are often beyond the reach of young people,

- a significant percentage of persons of near-retirement age which makes employees going into retirement in large numbers,

- difficult working conditions linked to numerous inconveniences and staying outside place of residence.

Besides the human factor, transport operators also use the means of transport in order to produce transport services. Using them involves generating a variety of costs. The most important costs associated with fixed assets owned by the companies in the transport sector include:

- prices of the means of transport,

- depreciation,

- rental, tenancy or lease costs,

- taxes and fees arising from using the means of transport.

The main form by which the fleet of the transport companies is financed has for years been a lease or a bank loan. A lease is a special form of financing investments 
which enables the company to obtain fixed assets needed by using them in exchange for payment. In practice this means concluding a contract according to which the owner of asset items authorizes the company to use those items over a definite period in exchange for a payment made in installments.

The loan, on the other hand, is a kind of a contract concluded with a bank under which the bank undertakes to grant a certain amount of money for a specified period earmarked for a specific purpose. The borrower is obligated to use the money in the manner specified in the contract, i.e. to repay the loan including interests on scheduled repayment dates and to pay commission (Andrzejczak 2012: 33).

However, as Angelika A. Kędzierska-Szczepaniak and K. Szczepaniak point out, the bank loan is a more advantageous source of financing investment than operating lease if one takes into account the varying time value of money. On the other hand, the lease can be more viable owing to such factors as tax preferences, lower initial capital or lesser financial requirements of lessors. These determinants have the effect that the lease (apart from one's own capital) is the only achievable form of financing a fleet (Kędzierska-Szczepaniak, Szczepaniak 2014: 21-23).

Moreover, Z. Witaszek suggests that the tax payment rules and simplified procedures of processing applications have a particular impact on the attractiveness of lease. Its advantage is lease flexibility in that the initial payment is specified and so is the payment schedule with the payments varying depending on the lessee's financial possibilities. The most common reason for choosing the lease is tax shield and transparent procedures (Witaszek 2008: 187-188).

The costs associated with choosing one form of financing over another play also an important role for many companies. Both loan installments and lease installments are estimated based on WIBOR rates. It can also happen that transport operators decide to borrow or lease in a foreign currency. Then the main indicator of costs will be LIBOR or EURIBOR rates. Depending on the contract, the costs of a lease or loan can change over the time of vehicle use.

Still, for many transport operators bearing the costs of external financing is very often the only possibility. That lease is very popular among transport companies is reflected in the numerical data. Over the period of 2008-2014, lease funds reported, with the exception of 2008, a rapid increase in the number of leased road tractors and 
semi-trailers (Chart 4). It is worth noting that 98221 vehicles were leased during the period under study. Moreover, Polish transport operators applied for the international license for the total of almost 41 thousand new vehicles over the period of 20082014. Thus, a significant portion of the fleet was leased.

Moreover, the analysis of the currency structure of leases shows that during the period in question on average $22.6 \%$ of operating leases of vehicles and on average $45.4 \%$ of leases was financed in foreign currencies.

\section{Chart 4. The number of road tractors and semi-trailers leased in Poland over the period of 2008-2014}

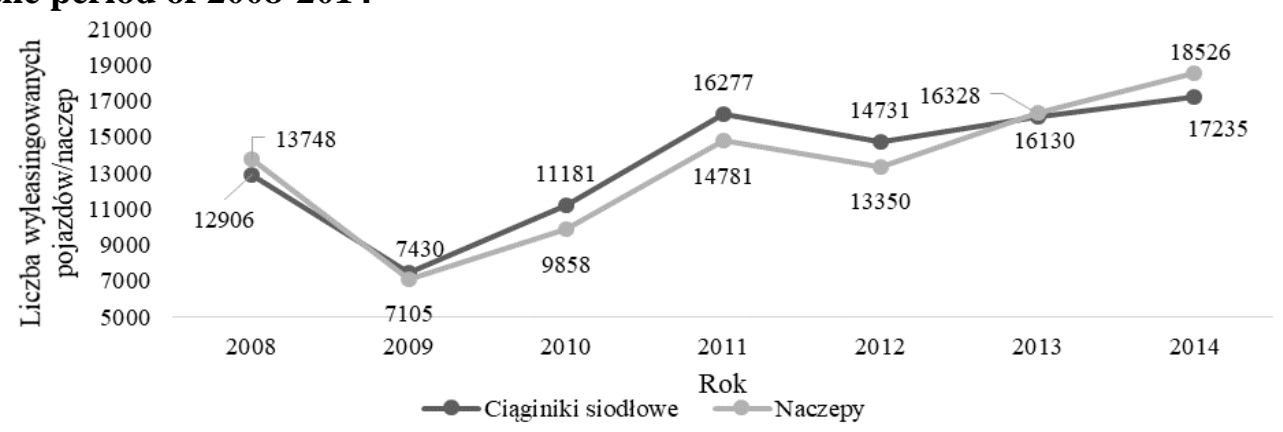

Source: self-reported data based on data obtained from the Polish Leasing Association

A transport company, just like any other economic entity, is required to bear tax burdens. Taxation is an extremely complex social, economic, political and institutional as well as legal phenomenon requiring to be considered from various points of view. A direct effect of taxes paid by economic entities is the transfer of funds from companies to the state budget. The structure of a tax system may affect the actual decisions on the size of investment, type of assets to be invested in, and what place to choose for the investment location. It can also change financial decisions concerned with the way in which investment will be financed and the proportion of distributed income (Podstawka, Deresz 2008: 127-128). The most significant taxes borne by transport operators include the following:

— taxes on income (PIT and CIT),

— indirect taxes (VAT and excise),

- taxes on wealth, 


\section{— road taxes in the form of toll.}

Income taxes are directly linked to income obtained by companies. As such they do not burden current operations, yet nevertheless they need to be taken into account for the company's economic outcomes. They can also change the financial decisions on the way investment will be funded and on the proportion of profit distributed to partners.

VAT, on the other hand, in general tends to be neutral for the company, since it can deduct input tax during the provision of its services. Also, companies which provide services for foreign customers do not pay taxes on transactions as providing cross-border transport services is VAT exempted.

Tax on the means of transport is one of the two levies, next to property tax, to be paid on account of assets owned. Legislator tied establishing and extinguishing tax obligation with the very fact of owning a carrier. This tax can be a considerable burden on transport companies holding a large fleet of vehicles (Goettel et al. 2011: 372).

Within the scope of local taxes, transport operators are also subject to property tax. The impact of this tax arises mainly from the fact that, apart from the place where the business is run, the entity, based on the provisions of the Road Transport Law, is supposed to have an operating center.

The impact of the costs of property tax on the activity carried out by the entity tends to be a disputable issue among those involved in the research on entrepreneurship. D. Renelta demonstrates the lack of correlation between the set of fiscal instruments and the stimulation function of taxation (Levine, Renelt 1992: 942943). In their analyses, E. Engen and J. Skinner go as far as to argue that there is a negative impact of the changes in taxation on the previously set non-fiscal goals. Moreover, given that the positive effects of tax stimulation occur occasionally and fluctuate between 0.2 and 0.3 of GDP annually, with equal, or even higher, costs of obtaining them, the authors consider them too weak to be used in an effective boost of socio-economic development (Engen, Skiner, 1996:618)

Drawing on Polish experiences in this respect, the studies conducted by T. Skic should be mentioned, which show, on the basis of empirical data recorded within the scope of tax stimulus impact, that there is a very weak correlation between the 
reduction of maximum rates of local taxes and the parameters describing the socioeconomic development of the local communities (Skica 2008).

Another category of costs are road charges. Since 2008, with the introduction of electronic devices for determining the road tall to be paid, a particularly dynamic development of the toll system has been visible. Next to fuel, the road toll is the most heavy item in the cost accounting. It can affect directly the transport operators' profitability and financial stability, for it influences the level of margin a transport operator receives per one kilometer covered. In a situation when there is much competition and raising prices is hardly possible, the road toll limits substantially the companies' profit.

\section{Research methods}

The study included the analysis of costs incurred by the transport sector companies in the West Pomeranian Voivodeship over the period of 2008-2014. The choice of the time horizon was dictated by having to compare the changes unfolding over time and to exclude circumstantial trends. In addition, numerous and important changes for international road carriers took place over the years 2008 to 2014. These include:

- Changes within the scope of pursuing the occupation of a road transport operator in 2009 through the introduction of Regulation 1071/2009/EC.

— Road toll system extension in Germany in 2009-2011.

— Introduction of electronic road toll system in Poland in 2011.

- Allowing Polish road carriers to carry out cabotage transport operation across the European Union in 2009.

The selection of companies was purposive in nature and was carried out on the basis of the data base made available by the Road Transport Office comprising companies holding international load transport license. A list of companies was generated from the data base which fulfilled the selection criteria in the form of the following requirements:

- The companies were in business for at least five years during the period 
under study.

- The companies held international freight transport license.

The outcome of the analysis was a list containing 705 companies which made up $36,3 \%$ of all the companies holding license in 2014 . The final study was carried out on a group of 103 transport operators for which it was possible to obtain complete financial data for the period examined. The data was obtained through InfoVerti data base and the National Court Register in the form of financial statements. The information on the submission of financial statements was obtained through notices of Court and Business Gazette.

Those qualified included companies with share capital and partnerships required to submit financial statements during the period in question. Given the lack of comparability arising from keeping, in the majority of cases, tax records, and also fiscal secrecy, obtaining data on natural persons and civil law partnerships was abandoned. A detailed description of the companies examined is presented in Table 1.

\section{Table 1. Description of entities examined}

\begin{tabular}{|l|c|c|c|}
\hline Legal form & $\begin{array}{c}\text { Companies qualified } \\
\text { for the study }\end{array}$ & $\begin{array}{c}\text { Companies } \\
\text { covered by the } \\
\text { study }\end{array}$ & $\begin{array}{c}\text { Share (\%) of } \\
\text { companies covered } \\
\text { by the study in all } \\
\text { the companies }\end{array}$ \\
\hline Natural person & 506 & 0 & 0 \\
\hline Joint-stock company & 0 & 0 & 0 \\
\hline Civil law partnership & 28 & 0 & 0 \\
\hline Partnership & 39 & 23 & 59.0 \\
\hline Limited partnership & 3 & 2 & 66.7 \\
\hline $\begin{array}{l}\text { Partnership limited } \\
\text { by shares }\end{array}$ & 1 & 1 & 50.0 \\
\hline $\begin{array}{l}\text { Sp. z o.o. sp.k. } \\
\text { (Limited partnership } \\
\text { formed with a } \\
\text { limited liability } \\
\text { company) }\end{array}$ & 2 & 1 & 60.3 \\
\hline $\begin{array}{l}\text { Limited liability } \\
\text { company }\end{array}$ & 126 & 76 & 14.6 \\
\hline Total & 705 & 103 & \\
\hline
\end{tabular}

Source: self-reported data based on the study results. 
In order to carry out the study and arrive at final conclusions a vast body of material had to be collected encompassing financial statements of 103 companies spanning the period of 2008-2014, which gave in total 618 balance sheets, profit and loss accounts and other information included in those items. The companies were assigned to individual size classes based on the guidelines of the European Commission recommendation of May 2003, 2003/361/EC.

The methods of descriptive statistics were used to prepare the data, which is linked to non- randomness of the sample with the results referring to the entities examined. In the production of results, statistical methods were employed as well as elements of economic and financial analysis. The information was combined with the financial data, processed using a data base created by MS EXCEL program and Power Query append. The results were produced using MS EXCEL 2013 and Statistica version 12.5 programs.

\section{The study results}

The average level of costs per one company under study constituted the basic measure allowing the changes unfolding to be assessed in nominal terms. In the years 2008 to 2014 this indicator was higher than for all the companies registered in Poland and in sector $\mathrm{H}$ of PKD (Polish Classification of Activities). During the period in question there was an increase in costs in Poland by $22.1 \%$ in the private business sector. Moreover, the costs in the group studied grew by $40.6 \%$ over the same period, of which the highest increase occurred between 2010 and 2011 (by $16.2 \%)$. Chart 5 presents a detailed characterization. 
Figure 5. Average costs in the companies examined, in all the companies in Poland and in PKD H sector in the years 2008-2014

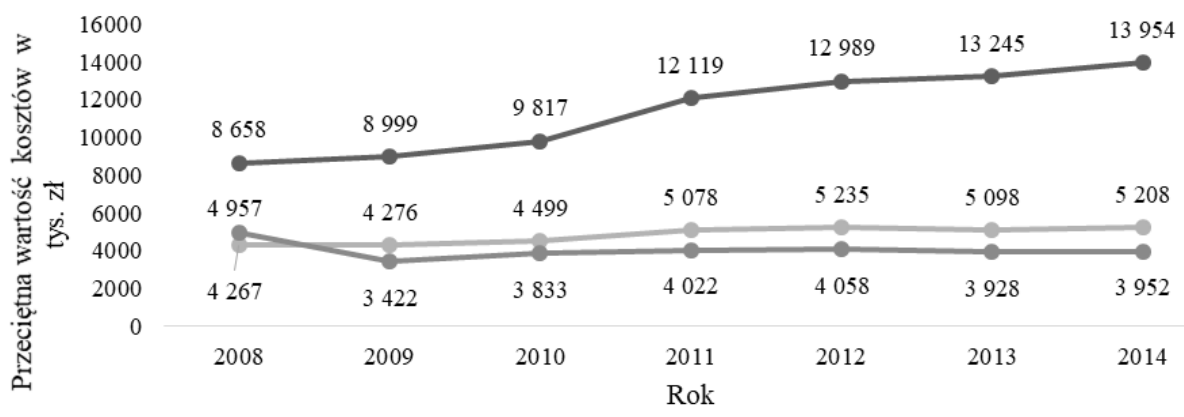

$\multimap$ Badana grupa ogółem $\quad \longrightarrow$ Ogólem w Polsce $\quad \longrightarrow$ Ogólem w sektorze H w Polsce

Source: self-reported data based on the Author's own study and data of the GUS (Central Statistical Office) Local Data Bank https://bdl.stat.gov.pl/BDL/dane/podgrup/temat/25/565/1599, [15.12.2016].

From the perspective of the size class, medium-sized enterprises showed the highest cost ratio with the micro-ones recording the lowest ratio (Table 2). Analyzing the growth rate involved in cost variations, it needs to be emphasized that over the period of 2008-2014 the highest increase was recorded in micro-enterprises (average annual growth $137.3 \%$ ), followed by a group of enterprises defined as small $(107.8 \%)$ and medium $(101.8 \%)$.

Table 2. The costs incurred by enterprises under study in the years 2008-2014 by category and legal form

\begin{tabular}{|l|c|c|c|c|c|c|}
\hline \multirow{2}{*}{ Items } & \multicolumn{7}{|c|}{ Year } \\
\cline { 2 - 7 } & 2008 & 2009 & 2010 & 2011 & 2012 & 2013 \\
\hline Micro-enterprises & 1735 & 2277 & 3876 & 5510 & 7095 & 8370 \\
\hline Wd & - & 131.2 & 170.2 & 142.2 & 128.8 & 118 \\
\hline Small enterprises & 7796 & 8023 & 8755 & 11034 & 11701 & 12214 \\
\hline Wd & - & 102.9 & 109.1 & 126 & 106 & 104.4 \\
\hline Medium enterprises & 27915 & 28366 & 29256 & 33148 & 33505 & 31464 \\
\hline Wd & - & 101.6 & 103.1 & 113.3 & 101.1 & 93.9 \\
\hline
\end{tabular}

$\mathrm{Wd}$ - growth ratio (previous year $=100 \%$ )

Source: self-reported data based on the study results. 
In order to gain insight into how individual costs affect the overall costs incurred by an enterprise, the analysis of the structure is most frequently used. In the period under study external services made up the largest portion of costs. Their share ranged from $28.2 \%$ in 2009 to $31.0 \%$ in 2010 (Fig. 6). In the standard chart of accounts transport operators classify the costs of loading and unloading, services provided within outsourcing and lease as external services.

Another cost making the largest portion of the total costs were expenses relating to the consumption of materials and energy. Their portion ranged from $29.3 \%$ in 2009 to $31.0 \%$ in 2012 . These expenses are mainly comprised of the costs of fuel, AdBlue solution, tires and parts relating to the operation of vehicles.

The third cost in terms of the cost share was made up of all other costs classified by type which on average varied between $17.4 \%$ and $23.4 \%$, depending on the year. In applying the standard approach, a transport operator classifies the costs of insurance and travel expenses of employees as belonging to this category. The latter ones, in particular, represent substantial expenses for transport operators, making up the portion of the real payment for work done.

Figure 6. The share of individual costs in the companies in the years 2008-2014.

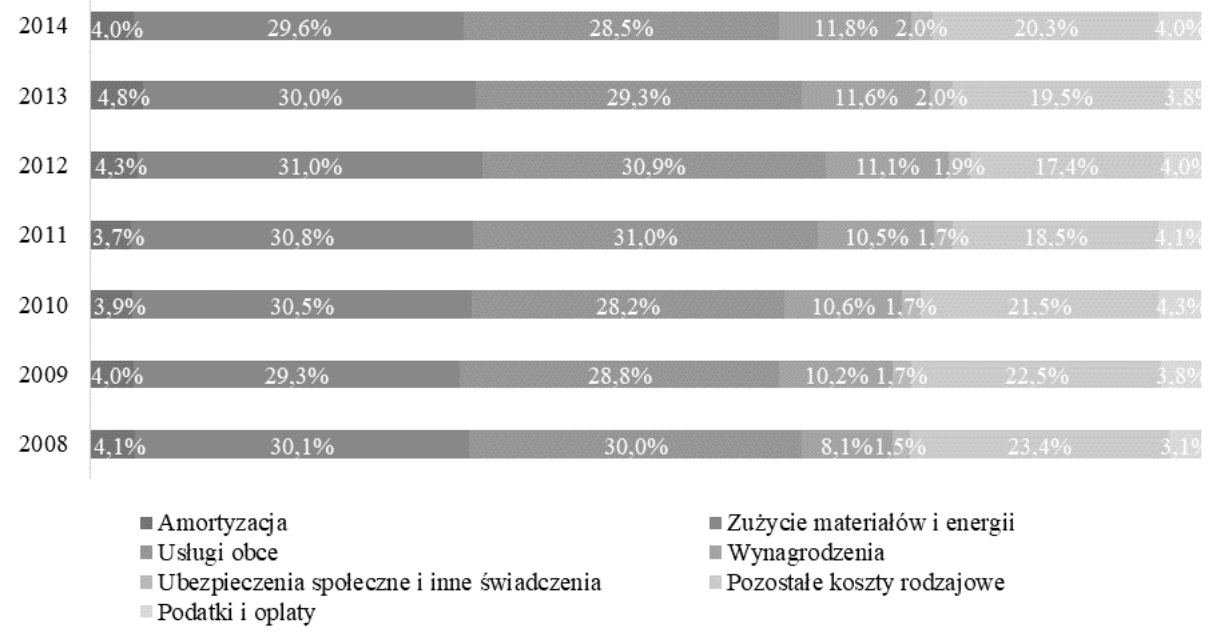

Source: self-reported data based on the study results. 
The first cost in the chart of accounts by type is depreciation relating to the progressive use of fixed and intangible assets. In terms of its share, depreciation did not represent a substantial percentage of the costs of companies examined. Its average value was at a level ranging from 3.3\% in 2010 to 3.8\% in 2013 and 2014 (Table 3).

Table 3. Depreciation share in the costs of the companies in the years 2008-2014.

\begin{tabular}{|l|c|c|c|c|c|c|c|}
\hline \multirow{2}{*}{ Items } & \multicolumn{7}{|c|}{ Year } \\
\cline { 2 - 8 } & 2008 & 2009 & 2010 & 2011 & 2012 & 2013 & 2014 \\
\hline Total & $3.8 \%$ & $3.7 \%$ & $3.3 \%$ & $3.4 \%$ & $3.6 \%$ & $3.8 \%$ & $3.8 \%$ \\
\hline Micro-enterprises & $4.1 \%$ & $4.0 \%$ & $3.9 \%$ & $3.7 \%$ & $4.3 \%$ & $4.8 \%$ & $4.0 \%$ \\
\hline Small enterprises & $2.7 \%$ & $2.7 \%$ & $2.5 \%$ & $2.7 \%$ & $2.1 \%$ & $1.9 \%$ & $2.0 \%$ \\
\hline Medium enterprises & $4.7 \%$ & $4.4 \%$ & $3.6 \%$ & $3.9 \%$ & $4.4 \%$ & $4.6 \%$ & $5.3 \%$ \\
\hline
\end{tabular}

Source: self-reported data based on the study results

The small share of depreciation in the total costs indicates that the companies analyzed did not have a significant number of the means of transport classified as such in the fixed asset register. This is the result of the commonly used practice of financing the fleet by way of a lease. Vehicles to be leased based on the most widespread form of lease - operating lease - are depreciated by the lessor (lease fund).

The share of depreciation in the costs was the biggest in the medium-sized enterprises, which in general had more assets not only in the form of vehicles but also buildings and equipment, thus making the share of depreciation larger than in micro-enterprises. In addition, their financial basis was big enough to receive a loan and purchase the fleet using their own funds.

This is confirmed by the analysis of the sources of investment financing which was determined based on the notes to the financial statements. For the entities investigated, the most popular proved to be a loan (43.3\%) and lease (42.7\%). Only $12.4 \%$ of enterprises used their own funds to finance investments (Table 4). 
Table 4. Financing investment sources in entities under study

\begin{tabular}{|l|c|c|c|c|}
\hline Items & Own funds & Loan & Lease & Other \\
\hline Total & $12.4 \%$ & $43.3 \%$ & $42.7 \%$ & $1.6 \%$ \\
\hline Micro-enterprises & $12.3 \%$ & $41.5 \%$ & $44.3 \%$ & $1.9 \%$ \\
\hline Small enterprises & $11.2 \%$ & $43.3 \%$ & $43.8 \%$ & $1.7 \%$ \\
\hline Medium enterprises & $20.8 \%$ & $50.0 \%$ & $29.2 \%$ & $0.0 \%$ \\
\hline
\end{tabular}

Source: self-reported data based on the study results

Another cost category recognized in the profit and loss account are the costs of the material and energy consumption which ranked as the third largest share in the total costs of the companies examined. The level of the costs in this category is mainly linked to the following factors:

- world market oil prices,

- foreign currency exchange rates, including in particular, the US dollar against Polish Zloty,

- wear and tear of fleet affecting the frequency of repairs,

- age of vehicles, which affects the consumption of motor fuels.

An increase in oil price on the world markets brings about, according to the effect of prosperity transfer, depreciation of the national currency against the US dollar. The growing prices of imported oil coupled with the low price elasticity of domestic demand lead to increased payments for raw material imports and the external deficit of the importer's economy, which makes the national currency weaker. Next, an increase in the exchange rate of the national currency against the US dollar and in the global price of raw material causes an increase in the price of oil expressed in national currency.

In addition to the effects exerted by the factors relating to the situation on the oil world market in 2008-2014, the level of excise duty and fuel surcharge varied as well, with the surcharge also determining the wholesale and retail price at gas stations. In 2008 the producer paid PLN 1048.00 on excise duty and PLN 93.69 of fuel surcharge per every 1000dm3 of diesel oil. In 2010 the excise duty remained stable, yet the fuel surcharge was raised up to PLN 233.99. In 2012 the excise duty grew up to PLN 1196.00 while the fuel surcharge up to PLN 249,92. In 2013 and 2014 the excise duty stayed at the level from the previous year, unlike the fuel 
surcharge which grew by PLN 10.00 and PLN 2.60 respectively. Figure 7 illustrates the extent to which the average price of diesel in a given year affected the share of the costs of material and energy consumption in the companies analyzed.

The costs of material and energy consumption made up the largest portion in the costs of micro-enterprises (from $30.3 \%$ to $34.5 \%$ ), while enterprises with over 50 employees saw the smallest share (between $26.6 \%$ and 28.2\%). The relationship indicated is primarily linked to the range of costs incurred by the individual firms.

Figure 7. The correlation between oil prices and the share of material and energy consumption costs in the companies in the years 2008-2014

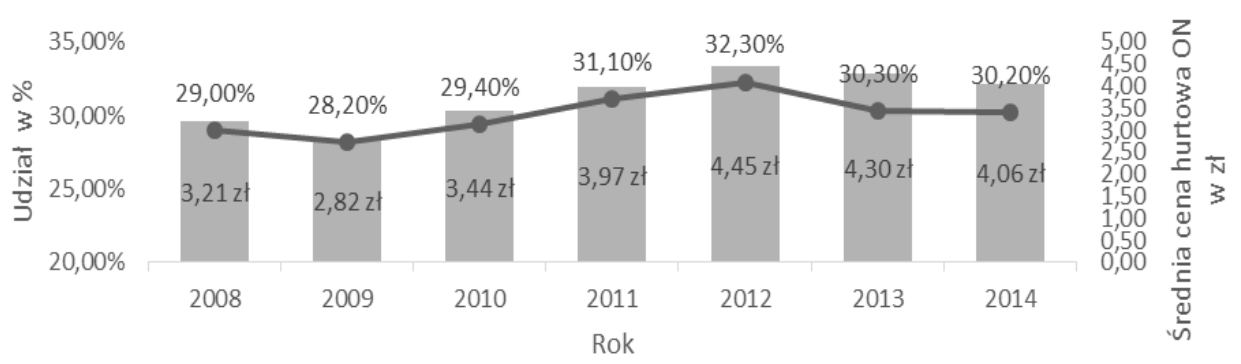

Średnia cena ON —Udział \% kosztów zużycia materiałów i energii

Source: self-reported data based on the study and average wholesale fuel prices of Lotos Group S.A. https://www.lotos.pl/145/type,oil_eurodiesel/poznaj_lotos/dla_biznesu/hurtowe_ceny_paliw/ archiwum_cen_paliw, [15.12.2016].

Since small economic operators, seeking to economize in a number of areas, incur additional costs to a lesser degree, the costs of fuels and repairs influence considerably their expenses. Medium enterprises, on the other hand, having larger resources and factors of production incur higher costs also in other areas of their business. Moreover, larger economic operators enjoy a better market position in terms of oil price negotiations and discounts received on account of a much bigger fleet. A detailed description is presented in Table 4.

The costs of external services made up the biggest percentage of the costs borne by the companies examined. As already indicated before, these costs, apart from telecommunication, property rental and accounting expenses, also include lease payments which largely determine the level of these costs. 
Table 4. The share of material and energy consumption costs in the costs borne by the companies in the years 2008-2014

\begin{tabular}{|l|c|c|c|c|c|c|c|}
\hline \multirow{2}{*}{ Items } & \multicolumn{9}{|c|}{ Year } \\
\cline { 2 - 9 } & 2008 & 2009 & 2010 & 2011 & 2012 & 2013 & 2014 \\
\hline Total & $29.0 \%$ & 28.2 & 29.4 & 31.1 & 32.3 & 30.3 & 30.2 \\
\hline Micro-enterprises & $31.3 \%$ & 30.3 & 34.5 & 34.0 & 32.8 & 31.9 & 31.5 \\
\hline Small enterprises & $30.8 \%$ & 30.0 & 29.1 & 31.1 & 32.9 & 31.0 & 30.8 \\
\hline Medium enterprises & $28.2 \%$ & 27.6 & 27.9 & 27.4 & 27.4 & 27.1 & 26.6 \\
\hline
\end{tabular}

Source: self-reported data based on the study results

Lease costs are largely determined by the level of interest rates. A lease is a form of credit with calculations being carried out on the basis of WIBOR rate, which depends on the reference rate of National Bank of Poland (NBP). Raising interest rates by the Monetary Policy Council is to the disadvantage of the companies for it affects the lease cost. Cutting interest rates, on the other hand, should benefit the companies as it plays a role in reducing the installment paid.

The findings show that there was a relationship between the NBP average reference rate and the share of external service costs in the total costs over the period analyzed. The decline in interest rates caused a slight reduction in the companies' outlays and their share in all the costs, which is particularly visible in 2011-2014. The share of the costs was still at a high level because of the growing number of vehicles whose purchase was largely financed by a lease (Fig. 8).

Figure 8. The correlation between the share of external service costs in total costs and the NBP reference interest rate in the years 2008-2014

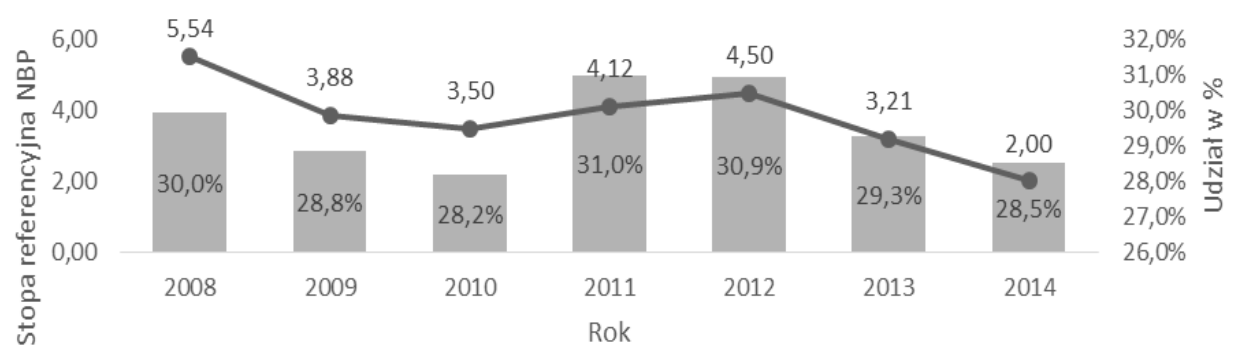

Source: self-reported data based on the study results 
As showed before, the share of external service costs in the companies varied over the course of the period under study. Until 2013, they fell mostly on the costs borne by micro-enterprises, whereas since 2013 they affected the costs of small enterprises to a larger degree. For medium enterprises, these costs made up on average from $21.2 \%$ of the costs in 2009 up to $27.4 \%$ in 2011 (Table 5).

Table 5. The share of external service costs in the costs borne by the companies in the years 2008-2014

\begin{tabular}{|l|c|c|c|c|c|c|c|}
\hline \multirow{2}{*}{ Items } & \multicolumn{7}{|c|}{ Year } \\
\cline { 2 - 9 } & 2008 & 2009 & 2010 & 2011 & 2012 & 2013 & 2014 \\
\hline Total & 30.0 & 28.8 & 28.2 & 31.0 & 30.9 & 29.3 & 28.5 \\
\hline Micro-enterprises & 31.3 & 30.3 & 29.1 & 34.0 & 32.8 & 29.4 & 28.4 \\
\hline Small enterprises & 30.6 & 29.0 & 28.8 & 31.6 & 32.9 & 31.6 & 30.7 \\
\hline Medium enterprises & 28.0 & 27.2 & 26.6 & 27.4 & 27.1 & 26.8 & 26.4 \\
\hline
\end{tabular}

Source: self-reported data

Taxes and local fees made up on average $3.9 \%$ of all the costs borne by the companies. Their level depends on such factors as the standard of exhaust emission, the number of kilometers driven on tolled roads and the number of vehicle axles. Their burden fell mostly on small enterprises (on average 4.0\%), with microenterprises being the least burdened in this respect. Their share in the costs grew from 0.9 percentage points compared to 2008 (Table 6). This was due to the changes in the tax rates on the means of transport and the implementation of the electronic toll system (e-toll).

Table 6. The share of tax and toll costs in the costs borne by the companies in the years 2008-2014

\begin{tabular}{|l|c|c|c|c|c|c|c|}
\hline \multirow{2}{*}{ Items } & \multicolumn{7}{|c|}{ Year } \\
\cline { 2 - 9 } & 2008 & 2009 & 2010 & 201 & 201 & 201 & 201 \\
\hline Total & $3.1 \%$ & $3.8 \%$ & $4.3 \%$ & 4.1 & 4.0 & 3.8 & 4.0 \\
\hline Micro-enterprises & $3.0 \%$ & $3.9 \%$ & $4.6 \%$ & 4.3 & 3.8 & 3.1 & 3.4 \\
\hline Small enterprises & $2.7 \%$ & $3.6 \%$ & $4.3 \%$ & 3.9 & 4.2 & 4.4 & 4.6 \\
\hline Medium enterprises & $3.6 \%$ & $3.9 \%$ & $3.9 \%$ & 4.0 & 4.0 & 4.0 & 4.0 \\
\hline
\end{tabular}

Source: self-reported data based on the study results 
Owing to the upgrading of the companies' fleet, the share of these costs did not show an excessive growth during the six-year time frame of the research. Since 2011 the number of vehicles meeting the emission level EURO 5 and above started to increase. In 2008 the companies used only 210 vehicles with EURO 5 type-approval, which made up $11.2 \%$ of the entire fleet, in 2011 the number of this type of vehicles grew up to $480(21.8 \%)$, with 2014 seeing that number at 1084 vehicles $(37.4 \%$ of the fleet).

Moreover, the number of vehicles with emission level EURO 3 and below declined. In 2008 vehicles of this type made up $60.8 \%$ of the fleet used, while in 2014 it was only $26.2 \%$. Nevertheless, a substantial number of the companies still used vehicles EURO 3 and EURO 4 (43.4\%) in 2014. However, even in those companies one could observe a downward trend. In addition, there was a clear increase in the number of most advanced vehicles meeting level EURO 6. In 2008 none of the companies owned such vehicles, while in 2014 they made up as many as $16.7 \%$ of all vehicles (Fig. 9).

Figure 9. The number of vehicles by their emission level used by the companies in the years 2008-2014

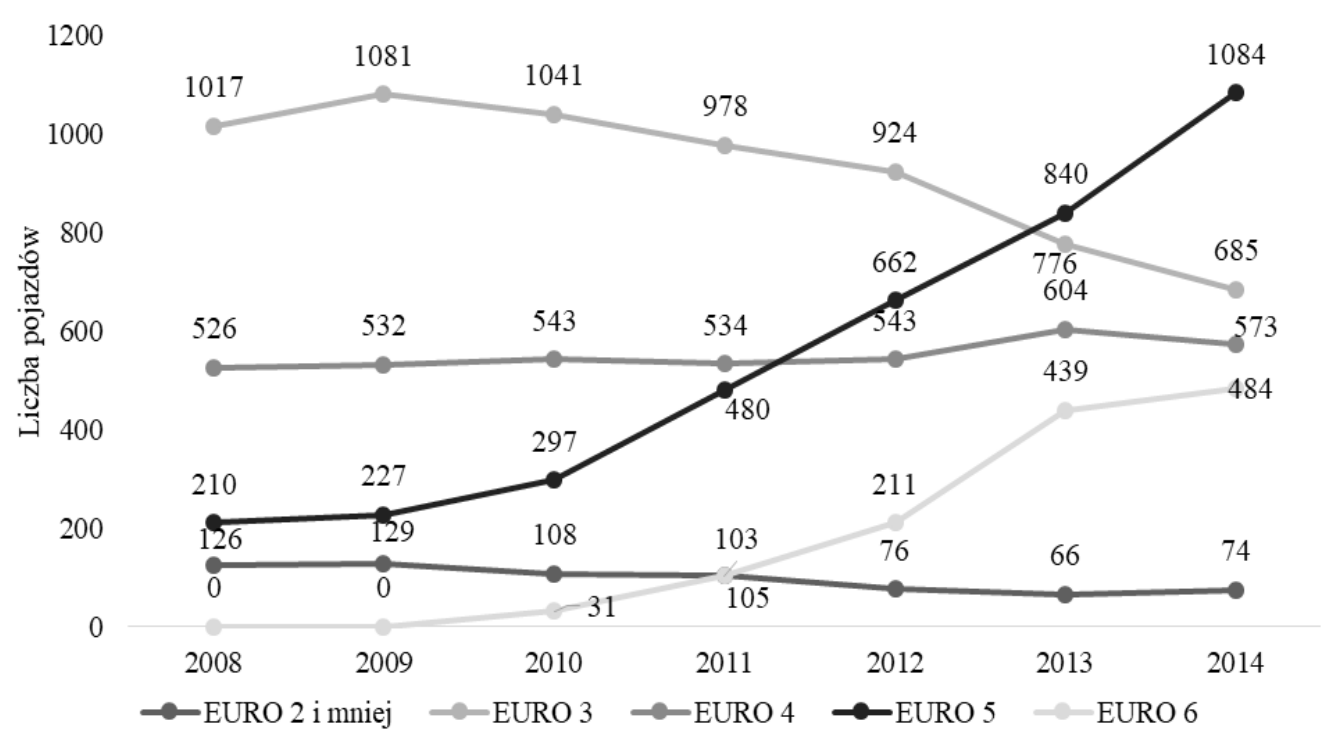

Source: self-reported data based on the study results 
Another category of costs analyzed was the one covering salaries and social security contributions paid by employers on account of the salaries. These costs are linked with each other and depend on:

- the minimum wage level in the country in a particular year,

- the average wage level in the given sector of enterprises,

- situation on the labor market.

As already indicated before, the period under study saw an increase in the salaries paid in the transport sector, especially those of drivers, who represent the key workforce resource of transport operators. The declining number of professional drivers made the shortages on the supply side of the driver labor market grow, while the demand kept on growing as the result of the increase in the number of vehicles in transport undertakings. Moreover, social security paid by employers grows proportionately to the increase in salaries.

The share of salaries in the costs in the companies examined represented on average $10.6 \%$ over the period analyzed, with small enterprises incurring the biggest share (on average $11.4 \%$ ), while medium enterprises' share in this respect was the smallest (on average 9.9\%). Further to that, these costs were stable in medium enterprises during the period in question. This is related to the higher wage level, and thereby lesser vulnerability to the changes of minimum wage (Table 7).

High labor costs sometimes induce employers (in particular, small firms) to look for new "alternative" forms of employment - not always entirely legal. One of such forms involves hiring employees on a part-time basis or for a lower than actual pay and paying the worker a portion (not infrequently the larger one) of his salary without it showing on the payroll, that is, without formal confirmation as to the salary amount received.

That this practice is wide-spread is mentioned in the report of the Civil Development Forum. According to it, this problem concerns almost 2 million workers with their salaries being paid by employers in the shadow economy. The report cites the GUS data which state that as many as 57\% of workers in microenterprises officially earn the minimum wage, whereas in companies employing over 9 persons this percentage was below 5\% (Shadow Economies in the Baltic Sea Region 2015: 19). Such huge discrepancies suggest that only a portion of salaries is 
paid in micro-enterprises, which seeking to cut down on costs are willing to pay salaries under the table. The analysis of the data gathered shows that it was the micro-enterprises which were most vulnerable to the changes in the minimum pay, and thus the costs relating to its rise.

Table 7. The share of salary costs in the costs of the companies in the years 2008-2014

\begin{tabular}{|l|c|c|c|c|c|c|c|}
\hline \multirow{2}{*}{ Items } & \multicolumn{7}{|c|}{ Year } \\
\cline { 2 - 9 } & 2008 & 2009 & 2010 & 2011 & 2012 & 2013 & 2014 \\
\hline Total & $8.1 \%$ & 10.2 & 10.6 & 10.5 & 11.1 & 11.6 & 11.8 \\
\hline Micro-enterprises & $6.7 \%$ & 11.2 & 10.5 & $9.9 \%$ & 11.1 & 11.5 & 11.9 \\
\hline Small enterprises & $9.2 \%$ & 10.6 & 11.2 & 11.4 & 11.6 & 12.7 & 12.8 \\
\hline Medium enterprises & $8.5 \%$ & $8.7 \%$ & 10.1 & 10.3 & 10.7 & 10.6 & 10.7 \\
\hline
\end{tabular}

Source: self-reported data based on the study results

Social security itself did not represent a substantial share in the costs of the economic operators analyzed - on average $1.8 \%$. Its burden tended to be the highest in medium enterprises (on average 2.2\%), the lowest in micro-enterprises (on average $1.3 \%$ ) - Table 8 . This is linked to the relationship indicated above in line with which bigger companies are willing to pay higher contributions, paying salaries to a lesser extent beyond the shadow economy and therefore their burden incurred on account of salaries is higher.

Table 8. The share of social security and other allowances costs in the costs of the companies in the years 2008-2014

\begin{tabular}{|l|c|c|c|c|c|c|c|}
\hline \multirow{2}{*}{ Items } & \multicolumn{7}{|c|}{ Year } \\
\cline { 2 - 8 } & 2008 & 2009 & 2010 & 2011 & 2012 & 201 & 201 \\
\hline Total & $1.5 \%$ & $1.7 \%$ & $1.7 \%$ & $1.7 \%$ & $1.9 \%$ & 2.0 & 2.0 \\
\hline Micro-enterprises & $1.1 \%$ & $1.4 \%$ & $1.1 \%$ & $1.0 \%$ & $1.3 \%$ & 1.5 & 1.9 \\
\hline Small enterprises & $1.8 \%$ & $1.7 \%$ & $1.8 \%$ & $1.9 \%$ & $1.9 \%$ & 1.9 & 1.9 \\
\hline Medium enterprises & $1.7 \%$ & $2.0 \%$ & $2.1 \%$ & $2.1 \%$ & $2.4 \%$ & 2.7 & 2.3 \\
\hline
\end{tabular}

Source: self-reported data based on the study results

Other costs by types in transport companies are primarily related to insurance and travel costs of employees. Over the period of 2008-2014 the following changes 
ocurred in the external environment in terms of these costs:

- changes in the rates of motor TPL insurance for car vehicles,

- change in 2013; Ordinance of the Minister of Labor and Social Policy of 29 January 2013 on payments due to an employee of a state or a selfgovernment unit financed with the state budget in connection with a business trip, which introduced higher payments also for private undertakings,

- delivery of the Supreme Court judgment (Ref. No II PZP 1/14) which adopted an interpretation that was unfavorable to carriers with respect to the provisions on payments for accommodation for the night in the driver's cabin.

Over the period under study the market for motor insurance was characterized by a progressive reduction of basic insurance policy prices, which was caused by the growing competition between insurers. However, the nature of the amount of premiums is not uniform as to be able to show that it has a direct impact on the cost level, given that insurance companies apply multivariate algorithms for their calculations. Plenty of enterprises which lease vehicles have the possibility to add insurance premiums to lease rental payments. If this is the case, the premium is most likely not to be recognized as a separate cost item.

The level of this category of costs was predominantly affected by the expenses relating to business trips. Allowances represent a form of partial payment of salaries in many firms with their advantage being that it is not necessary to make deductions on account of income tax and contributions to social security. Thus, they reduce the level of costs incurred by the economic operator which arise from the real amount of pay.

Until 2014 the general interpretation of the provisions of law in this respect provided enterprises with freedom in terms of setting their rates depending on the internal provisions of labor law legislations. In 2014, in line with the new interpretation of the legislation issued by the Supreme Court, transport operators were required to pay a lump sum for accommodation for the night in the driver's cabin according to the amount set out in the Ordinance of the Minister of Labor and Social Policy of 29 January 2013.

The remainder of the costs by type grew in all the categories. In particular, their 
share began to increase since 2013. Moreover, economic operators employing a workforce of over 50 had the largest share of these costs in their total costs (on average $25 \%$ ), with micro-enterprises having the smallest share (17.4\%). A detailed description is presented in Table 9.

Table 9. The share of other costs by type in the costs of the companies in the years 2008-2014

\begin{tabular}{|l|c|c|c|c|c|c|c|}
\hline \multirow{2}{*}{ Items } & \multicolumn{7}{|c|}{ Year } \\
\cline { 2 - 8 } & 2008 & 2009 & 2010 & 2011 & 2012 & 2013 & 2014 \\
\hline Total & $23.4 \%$ & $22.5 \%$ & $21.5 \%$ & $18.5 \%$ & 17.4 & 19.5 & 20.3 \\
\hline Micro-enterprises & $22.6 \%$ & $18.9 \%$ & $16.3 \%$ & $13.1 \%$ & 13.9 & 17.8 & 18.9 \\
\hline Small enterprises & $22.2 \%$ & $22.4 \%$ & $22.3 \%$ & $17.4 \%$ & 14.4 & 16.5 & 17.2 \\
\hline Medium enterprises & $25.3 \%$ & $26.2 \%$ & $25.8 \%$ & $24.9 \%$ & 24.0 & 24.2 & 24.8 \\
\hline
\end{tabular}

Source: self-reported data based on the study results

\section{Conclusions}

The decisions made by enterprises may substantially affect individual costs incurred by companies in running their business. An ongoing analysis of the individual costs enables an entity to react quickly to the changing market conditions. Therefore, the optimization of finances of transport companies should be subject to an ongoing managerial supervision.

At the same time, the findings obtained allow the impact of the individual macroeconomic factors on the costs incurred by companies to be analyzed. In this paper the focus was mainly on the general determinants with the analysis of the micro-factors being omitted. This results largely from having to engage greater outlays in the form of conducting a survey.

The majority of the factors which had an impact on the cost variations was beyond direct influence of the transport operators analyzed. Still, if reacting accordingly, the individual companies could implement an adaptation process aimed at alleviating the changes taking place in their environment. The two most important cost determinants in the transport sector include the labor market which during the period under study led to the decline in supply of qualified staff, thus contributing to 
increased salaries, and fuel price which is dependent on oil production. However, it should be emphasized that the taxes and fees subject to the budget policy also exerted influence on the burden borne by the companies. Moreover, microenterprises were more vulnerable to the impact of external factors having less room for maneuver in terms of negotiations as well as having limited capital resources.

The increase in the overall level of costs indicated over the period of 2008-2014 does have an impact on competitiveness of the companies under study. Higher costs result in the Polish transport operators having smaller advantage over the competing companies from Western Europe. This process which is very much connected with increased salaries will surely lead to a decline in profits in the upcoming years.

While in 2008 Polish companies could take advantage of the lower fuel prices and lower wages compared to the countries of the "old" Union, the changes that occurred over the period examined suggest that this advantage grew smaller. There is no doubt that the managers of transport companies should look for new opportunities to penetrate the market in that they should improve the quality of their services as well as retain contracts for regular services.

Considering that the findings gathered pertain in their majority to limited liability companies and limited partnerships, referring them to enterprises in general may be done, yet with considerable caution. Moreover, the study is general in its nature having exhausted not all the factors determining the costs in the road transport of goods, in particular, the external factors. One should, therefore, conclude that in order to explore more extensively this topic, it would be advisable to carry out an analysis focusing, in particular, on companies of natural persons as they represent the most numerous group of economic operators in this sector.

\section{Bibliography}

Andrzejczak D. (2012), Podstawy działalności handlowej, Wydawnictwo WSIP, Warszawa 2012.

Engen E., Skiner J. (1996), Tax policy in the real world, Cambridge University Press, Cambridge.

Goettel A., Goettel M., Lemonnier M., Orłowski J. (2011), Instytucje prawa cywilnego w konstrukcji prawnej podatków, Wydawnictwo Wolters Kluwer, Warszawa.

Kędzierska-Szczepaniak A., Szczepaniak K. (2014), Kredyt czy leasing? Porównanie kosztów finansowania inwestycji, „Journal of Management and Finance”, vol. 12 no. 4, pp. 21-23. 


\section{Błażej SUPROŃ}

Kocór M., Strzebońska A., Dawid-Sawicka M. (2015), Rynek pracy widziany oczami pracodawców, Polska Agencja Rozwoju Przedsiębiorczości, Warszawa.

Ledkewicz A. (2014), Uwarunkowania samoregulacji cenowo-kosztowej przedsiębiorstw transportu drogowego ładunków, „Zeszyty Naukowe Uniwersytetu Szczecińskiego, Problemy transportu i logistyki”, vol. 25, pp. 143-154.

Levine R., Renelt D., A (1992), Sensitivity analysis of cross - country growth regressions, "The American Economic Review”, vol. 82 no. 4, pp. 942 - 963.

Podstawka M., Deresz A. (2008), Podatek dochodowy od osób fizycznych a wzrost gospodarczy, „Zeszyty Naukowe SGGW w Warszawie. Problemy Rolnictwa Światowego”, vol. 5 no. 20, pp. 126132.

Shadow Economies in the Baltic Sea Region 2015,

https://for.org.pl/pl/d/6514ab076c02d746c7ba387bf6bb3977 [20.08.2016].

Skica T. (2008), Instrumenty wspierania przedsiębiorczości przez samorząd terytorialny (na przykładzie gmin województwa podkarpackiego, ,Samorząd Terytorialny”, vol. 2, pp. 43-62.

Średnie hurtowe ceny paliw PKN Orlen,

http://www.orlen.pl/PL/DlaBiznesu/HurtoweCenyPaliw/Strony/Archiwum-Cen.aspx [15.11.2016].

Średnie cen hurtowe paliwa Grupy Lotos S.A,

https://www.lotos.pl/145/type,oil_eurodiesel/poznaj_lotos/dla_biznesu/hurtowe_ceny_paliw/archiwum _cen_paliw, [15.12.2016].

Waśkiewicz, J., Balke, I. (2012), Średnie koszty 1 wozokilometra przebiegu oraz ich struktura rodzajowa w badanych polskich przedsiębiorstwach ciężarowego transportu samochodowego w latach 2009 - 2011 i w I półroczu 2012 r., „Transport Samochodowy”, vol. 4, pp. 5-20.

Witaszek Z. (2008), Leasing w funkcjonowaniu podmiotów gospodarczych w warunkach gospodarki rynkowej, „Zeszyty Naukowe Akademii Marynarki Wojennej”, vol. 172, pp. 175-190.

Witkowski K., Tanona K. (2013), Analiza kosztów transportu drogowego, „Logistyka”, vol. 5, pp. 411416.

Zawody deficytowe i nadwyżkowe w 2008 r. (2009), Departament Rynku Pracy MRPiPS.

Zimon G. (2015), Analiza kosztów w przedsiębiorstwach transportu samochodowego, „Zeszyty Naukowe Uniwersytetu Szczecińskiego, Finanse, Rynki Finansowe, Ubezpieczenia”, vol. 77, pp. 349354. 